\title{
Subordination of women and patriarchal gender relations at Islamic poor community
}

\author{
Subordinasi perempuan dan hubungan gender patriarki di komunitas \\ miskin Islam
}

\author{
Ahmad Ridwan \& Emy Susanti \\ Department of Sociology, Faculty of Social and Political Sciences, Universitas Airlangga \\ Address: Jalan Dharmawangsa Dalam, Surabaya, East Java 60286 \\ E-mail: emy_susanti@yahoo.com
}

\begin{abstract}
This study focuses on poor women in the social environment (village) in the center of the Surabaya metropolis with classical Islamic culture and rules. Social relations and "pesantren culture" are felt in this place. For example: women must wear headscarves every day, men use koko sarongs and shirts, reading the holy verses of the Qur'an are a daily habit. In fact, elementary school children have become memorizers of the Qur'an (hafidz). This place produces "kyai" and "nyai" (saints in Javanese Islam). This study focuses on unequal gender relations between men and women so that poor women experience subordination, as well as empowerment of poor women in the Islamic community in the middle of big cities. Women, especially poor women, have very low bargaining power because of the patriarchal culture and Islamic rules there. Even though poor women help to make a living for the family, all important decisions remain with the husband (male). The methodology used is qualitative. Conduct in-depth interviews with poor women who were married in that place. Researchers also make observations about their daily activities in the community. The result, using Michel Foucault's power relations theory analysis, found that poor women get unfair relationships every day. They always lose with their husbands in any case. They are always oppressed and subordinated. Poor women get a discourse that women are the second social class in this life. They are a male partner, not the first person. So, important decision makers in the family are always men, not women. Although women help their husbands to work outside the home, decision makers are always husbands. Poor women are also powerless in government development programs. Even though the relationship is not equal, all women accept it because it comes from God's destiny (Allah SWT). This phenomenon is real and occurs in the center of a big city (Surabaya) which is one of the largest cities in Indonesia.
\end{abstract}

Keywords: gender; poverty; power relations; women subordination

\begin{abstract}
Abstrak
Studi ini berfokus pada perempuan miskin dalam lingkungan sosial (kampung) di pusat kota metropolis Surabaya dengan budaya dan aturan Islam klasik. Hubungan sosial dan "budaya pesantren" sangat terasa di tempat ini. Sebagai contoh: perempuan harus mengenakan jilbab setiap hari, laki-laki menggunakan sarung dan kemeja koko, membaca ayat suci Al Quran adalah kebiasaan sehari-hari. Bahkan, anak-anak sekolah dasar telah menjadi penghafal Al Quran (hafidz). Tempat ini menghasilkan "kyai" dan "nyai" (orang suci dalam Islam Jawa). Penelitian ini berfokus pada hubungan gender yang timpang antara lakilaki dan perempuan sehingga perempuan miskin mengalami subordinasi, serta pemberdayaan perempuan miskin di komunitas Islam di tengah kota besar. Perempuan khususnya perempuan miskin memiliki daya tawar yang sangat rendah karena budaya patriarki dan aturan Islam di sana. Meskipun perempuan miskin turut membantu mencari nafkah keluarga, tetapi segala keputusan penting tetap berada padan suami (lakilaki). Metodologi yang digunakan adalah kualitatif. Melakukan wawancara mendalam dengan perempuan miskin yang menikah di tempat itu. Peneliti juga melakukan pengamatan tentang kegiatan sehari-hari mereka pada komunitas itu. Hasilnya, dengan menggunakan analisis teori relasi kuasa Michel Foucault, ditemukan bahwa perempuan miskin mendapatkan hubungan yang tidak adil setiap hari. Mereka selalu kalah dengan suaminya dalam hal apapun. Mereka selalu tertindas dan tersubordinasi. Perempuan miskin mendapatkan wacana bahwa perempuan adalah kelas sosial kedua dalam kehidupan ini. Mereka adalah pasangan laki-laki, bukan orang pertama. Jadi, pembuat keputusan penting dalam keluarga selalu laki-laki bukan perempuan. Meskipun perempuan membantu suami mereka untuk bekerja di luar rumah, pembuat keputusan selalu suami. Perempuan miskin juga tidak berdaya dalam program pembangunan dari pemerintah. Meskipun hubungan itu
\end{abstract}


tidak setara, tetapi semua perempuan menerimanya karena berasal dari takdir Tuhan (Allah SWT). Fenomena itu nyata dan terjadi di pusat kota besar (Surabaya) yang merupakan salah satu kota terbesar di Indonesia.

Kata kunci: gender; kemiskinan; relasi kuasa; subordinasi perempuan

\section{Introduction}

Poor women have tended to be passive in accepting ideas or norms from their surroundings. The choice of roles is limited and women are not given their basic rights humanely (Susanti 2007). A patriarchal system that prioritizes the position and role of men and they have a hegemony over women, especially in a society based on classical religion. Men are always the main, this fact shows that the bargaining power of women, especially poor women, is getting lower (Fakih 1996). Even though they contribute to the family economy, they actively participate in the community in their environment but their bargaining position and role are secondary roles after men. Social relations in the discourse of patriarchal hegemony resulted in women experiencing subordination in various aspects. The severity of knowledge of patriarchy obtained from generation to generation is a discourse agreed upon by the women themselves. In various communities, especially communities that strongly support patriarchal hegemony on the basis of religious arguments. It is important to know that the government sets a poverty line that is income of IDR 401,220 per month and below (BPS, 2018). So that most women because of limited economic access, are unable to reach the poor standard threshold. So that they increasingly lack power in the presence of men. This will be exacerbated if it is included in a community location that is based on patriarchal social life.

Besides being susceptible to experiencing subordination in the family and social environment everyday. It turns out that women are also vulnerable to experiencing powerlessness in development programs. A study that had been done before in Indonesia by Heyzer (1986) when there was a village development program in which the means of production in rice fields were replaced with machines. Women who are constructed not in the operation of machine tools must finally be willing to lose their jobs because the process of cultivating rice fields is mostly done by men. Also the same study by Waltz (2016) in southern Brazil that women in the villages were treated differently from men even though the times had advanced so that shows that if the development program still often occurs gender bias.

This study will focus on poor women with all social relations they experience, especially unequal social relations in their families and community environments and the reality of their empowerment in development programs on social settings that are very strong patriarchal norms and cultures based on classical Islamic interpretations. The community is in the middle of a metropolitan city as big as Surabaya, one of the largest metropolitan cities in Indonesia. This community is located in the Sidosermo area and is better known by the surrounding community as "Kampung Ndresmo" or "Kampung Sidosermo Dalam". Although the subordinate model is almost the same as women's poverty research in Uganda by Fiske \& Shackel (2015), Ndresmo's social settings have no physical warfare.

The phenomenon seen in everyday social relations is that women in social discourse are the second social class and only become male companions. The discourse of knowledge is based on the text of the Qur'an in a textual manner. The main position in men and women is only second. Important decisions in social life are in men. The discourse has been passed down for generations and all men and women agree to the construction.

Actually studies on poverty and women have been done a lot before. Economic perspective, poverty, human rights, or socio-cultural studies have been carried out. It's just that there are not many who take a gender perspective where there are unequal relationships between men and women in an institution. An unequal gender relation is one of the strongest reasons why poor women from generation to generation have not been able to get out of the cycle of poverty. In addition, the burden of responsibility carried by women is far more severe when compared to men in an institution. They also have limited space for movement and choice of actions and roles, so the position of women always experiences subordination. Moreover, if it is in a social system based on patriarchal culture on 
the basis of the interpretation of classical Islam. it is still rare to assess women's poverty in a gender perspective in a strong Islamic-based environment

Using the theory of power relations thought theory by Foucault as a knife of analysis, there is a relationship of dominance between men and women. Foucault does not conceptually define what power is but emphasizes how power is practiced, accepted and seen as truth and functioning in various fields of life (Foucault 1990). Foucault sees power not as something that is owned. Power is a strategy, a verb, not a noun. The concept of power implies that power functions in a relationship or relationship, not only as a relationship between oppression and oppression. Interwoven manifests in a relationship that continues. Power relations can be family relationships, relationships that occur within an institution, etc (Santoso 2002).

One form of power relations is a domination relationship, where domination relations are asymmetrical power relations where subordinate subjects have limited space for maneuvering and limitations on choice of actions (Foucault 2002). So Foucault explained where there is a relation there is power. Power operates in all aspects of life. In the process power generates knowledge and knowledge produces power. There is a strong relationship between power and knowledge. That power can build discourse that is considered right. And the discourse was maintained to strengthen the position of one of the parties. Therefore, this power relations theory will be very suitable to be used to dissect and analyze the reality of this research. So that the hope is able to find a bright spot on the problem of poverty that is always experienced by poor women in a very patriarchal region.

\section{Research Method}

This study uses a qualitative research model which wants to understand in depth the phenomenon or reality (Neuman 2013). Of course the phenomenon that will be studied is the gender relations of poor women and the empowerment that they get. It is in the social setting of the Islamic community in the city of Surabaya, namely "Kampung Ndresmo". Using the technique of in-depth interviews and observations in the process of collecting data. There were eight informants and seven of them were subjects of research in the form of poor women in the poor category in poor households. One person is a religious teacher (ustadz) as an informant who provides additional data deeply in relation to that community. This ustadz was named Rofiq and was well known in that community and was a native of the "Ndresmo" and was a descendant of the clerics. Then he gave a list of poor women in the area according to the criteria. It should be remembered, when entering the social arena that is strong in its Islamic tradition, then if the male sex researcher must have a male person in that community as the entrance. Because it can't be easily outsiders, especially men want to examine women's lives. So that Rofiq is one of the bridges that can connect researchers with research subjects. Then determine seven women selected according to criteria and conducted in-depth interviews using interview guidelines. From the interview process then transcribed, classified based on the type of theme of the data according to the research, namely gender relations and empowerment experienced by poor women, then the data was analyzed by the theory of power relation by Foucault.

\section{Results and Discussion}

\section{Gender relations in the reproductive household (Poor women always get oppression)}

Gender relations experienced by women in poor households will appear in the process of their daily activities. As with the data already stated that in the Sidosermo Dalam (the future discussion will be used by the term "Ndresmo") it appears that the father or the husband does not work as an office employee or as an employee. They are many at home to study recitation and "majelis taklim". So that the burden of homework is on each wife. Regarding the division of labor, it can be seen in the following Nurjannah statement:

"I'm just a housewife... after dawn I prepare cooking, then take care of small children, clean the house, put the children to sleep, then every day washing clothes is helped by the biggest daughter ... every day is always like that." (Source: Interview with Nurjannah on Juni 27, 2018). 
Seeing such a reality, Nurjannah has been constructed for a long time that the role of women is in the domestic domain and that it is passed on to her daughter. Because boys at home are not given the responsibility to help with family matters such as washing clothes and so on. As shown in the following data:

"Who helped with my daughter's homework ... if the man didn't give me a burden because he had to go to school and had to memorize the Quran. Later, to be the same as his father, Ustadz. If the girl tomorrow is a housewife." (Source: Interview with Nurjannah on June 27, 2018).

Even sadder when women in "Ndresmo" are made to have a side job besides a housewife. Some sew, make cakes, open stalls and sell fried snacks. Their daily activities aside from taking care of domestic jobs but are also burdened with the business of seeking additional economic income. Worse, besides looking for additional income, the burden in the domestic domain is still held firmly and men are not obliged to assist domestic affairs. We can see from the story of Ms. Heni who is a housewife and makes cakes and sells everyday. The position of women is always constructed to bear domestic affairs.

"I sold cakes ... it made itself and then delivered it to stalls ... typical wet snacks such as lemper, steamed bread, and others wrapped in banana leaves. Cook it after the evening because it's dawn after it's delivered to the stalls ... I'm full cooking ... besides washing clothes, cleaning too." (Source: Interview with Heni on June 28, 2018).

In addition to full work, domestic affairs are also still charged to the women, and strangely men do not help, because her husband has a busy life of Koran and taklim. So it must be shared. The division of domestic labor which made the mother as the party with total domestic affairs was also felt by other mothers such as Yeni's mother, Nunun's mother and Ruqoyyah's mother. I take one example of Mrs. Yeni:

"... I take care of small children every day ... cook ... clean up ... and take care of my old inlaws ... his duty is for outside affairs." (Source: Interview with Yeni on June 27, 2018).

Not much different from mothers who have no dependents anymore because they have worked after graduating from SMK. This mother is Ms. Ruqoyyah who also sells fried foods. Even though he helped the family's economy, the physical burden was still imposed on him. As seen in his daily activities:

"I have 2 children who have graduated from Vocational High School and then work, every day I have a kitchen and clean my cleaning. Because of the father's business with the issue of recitation and taklim." (Source: Interview with Ruqoyyah on Juni 28, 2018).

Borrowing power relations theory from Foucault wherein there is a dominance relationship that refers to an unbalanced relationship experienced by subordinated parties where they have limited space for movement and choice of action. So, in this way, poor women in poor households are seen as dominated by husbands and this limits women's space. Knowledge of the construction has been going on for a long time and has become a hereditary discourse, so it's no wonder women themselves consciously agree to the discourse. Moreover, the religious argument is the basis, as narrated by Nurjannah as follows:

"Wife is joining her husband's paradise. We must accept that because it is already in the Qur'anic argument that the imam's husband is a family. If it is run "lillahi taala insha Allah" is peaceful and comfortable" (Source: Interview with Nurjannah on June 27, 2018).

So that the religion which was constructed patriarchally made women more oppressive. Berger (1990) states that religion is constructed to maintain certain values that are deliberately created by the society itself. Also related to financial management matters as obtained in the field data shows that if daily expenses are the responsibility of the wife because if managed by the husband for daily needs it will be destroyed. So the affairs of financial daily needs are borne by the wives. 
"When it comes to kids' pocket money ... cooking ... every day I turn the money ... if you hold it, you will be destroyed ...". (Source: Interview with Nurjannah on June 27, 2018).

Thus it is clear that woman as mothers while helping the family economy experience gender relations that are unequal in the domestic sphere where the fathers are not obliged to assist domestic affairs. Even male children are not told to help as well and instead girls are asked to help with homework such as washing or cleaning houses. This finding is similar to the research conducted by Susanti (2007) which is only different in the regional context. Seen in this village is more pathetic because there is religion as one of the supporting factors for the progress of gender inequality. Religion is a powerful weapon to hegemony women. Pun also strengthens the findings by Moser (1993) about women's poverty in Indonesia as a result of unequal gender relations.

\section{Gender relations in productive households}

In this aspect of the field, if we observe it, it will look very unfair to the process. As we know that the men in this community do not have a permanent job and are passively waiting when there is an invitation to recite outside and there is a "guardian" then they will get an envelope. So to cover the daily needs of poor mothers in Ndresmo, they make an effort to survive by selling cakes, fried foods and sewing. In the process of seeking additional income with the business, the husband does not help in the total business process. Because if you cook cakes, your husband can't, and you can't sell fried food. Because this husband has an average taklim assembly and every day focuses a lot on studies and taklim forums for deepening the Koran. So the mothers who are working hard to cover their daily needs.

"I made a cake ... cook it after the evening, because dawn had to be delivered to stalls ... entrusted the stall ... you don't help cooking ... usually just take it to the stall ... but often I" (Source: Interview with Heni on June 28, 2018).

With this, it can be seen that the wife's burden is higher than that of the father to seek family income. The husbands did get an envelope when invited to leave Ndresmo, but this was uncertain in time. So to survive everyday you have to sell. Even when income is minimal and has to issue urgent needs, mothers must first pay debt to the stall or look for loans just to meet kitchen needs. But when it comes to spending that is of a large nature, the father will find it.

“... owed first at the stall for kitchen matters ... if for example big expenses are his business, the main thing is your father if there is a big problem. The wife is mild for debt problems. Father usually owes first to a capable brother "(Source: Interview with Yeni on June 27, 2018).

In poor households in this place, husbands do not have regular income, but their position is highly prioritized because according to the mothers, they acknowledge that they as wives must follow what their husbands say. Because the wife's paradise is with their husbands. This shows that even though poor women push their bones to help their daily lives, the important decision makers and the main position are men. The men were constructed as the party that regulated and as the head of the household based on the Qur'anic argument so that they did not need to help in finding a daily economy because they assumed that they were usually invited to recitation out of the village and got a large envelope from there.

Moreover, the families here rely heavily on the moment of alms distribution. Because the existence of alms is very helpful for the family economy. So that women are more submissive to their husbands because men will often get alms because they often participate in "pengajian" and "taklim" inside and outside Ndresmo and have access to the public world. So the power relation is very visible in fulfilling the daily needs that husbands do not have to help sell or sew because they will later get a lot of alms funds.

"That ... alms is very helpful for life here ... because there is no assistance from the government ... which is mostly from alms" (Source: Interview with Rofiq on June 29, 2018).

The researchers initially wondered, the husband did not work and the wives were also looking for extra income accordingly. Then why can you still survive even with 7 children. Some even only sell 
fried foods but can send their children to school. It turns out that the interesting answer is that they have a dependency on the distribution of alms. Because in this place there are many "pesantren" when ahead of Eid Mubaraq, rich people issue "alms maal" and "fitrah" to pesantren. Pesantren will divide into the surrounding environment of the less fortunate. So that poor households will get abundant income.

In addition, the husbands also found that if they received an envelope from "taklim" outside and the amount was quite large, this would be saved for their daily lives. But unfortunately, the money taken for daily surrender by husbands to wives and those who play money are all wives. This shows once again the role of women in this place is very large compared to men because in addition to having to work regularly every day, they are charged with domestic affairs and the severity of turning money around for their daily needs. So do not be surprised if the wife has a keyword that does not feel heavy.

"All this has been Allah's destiny ... must be patient and sincere, thank you ... thankful ... the heart will be comfortable and peaceful ... this world is only temporary ... there has been an argument in the Qur'an.” (Source: Interview with Nurjannah on June 27, 2018).

With this, it seems clear that in the daily life process the poor women are subordinated by men where the process of subordination is agreed upon by women and they sincerely accept in the hope of getting a reward from God. Thus, it seems that the practice of the relationship of power between a husband and his wife in the daily productive field, both routine and non-routine, becomes a reality that must be accepted in a generous manner by women.

\section{Gender relations in the household of community management}

Although poor women help many economic activities of their families. But they were also involved in activities in the village, namely the Family Welfare Development or PKK-Pembinaan Kesejahteraan Keluarga. The agenda is arisan and pengajian. According to observational data in the field, there are also $P K K$ administrators who are part of Muslimat and fatayat. It's just that the container in this activity is under the auspices of the $P K K$. They routinely hold gatherings once a month and sometimes twice.

"... following the $P K K$, because there are recitation activities for mothers there ... can meet other friends ... mingle and exchange ideas ... if at home it's not nice if there is a need for neighbors." (Source: Interview with Heni on June 28, 2018).

Thus, even though this mother had a lot of work at home making cakes, she still took the time to join the $P K K$ community. This shows that poor women who already have a domestic burden and additional productive income activities still take the time to spend the $P K K$. Even though they are only limited to members, this shows that they have a fixed orientation responsibility so that when they need to be with neighbors it is not difficult.

As with other women who also have work at home to sew and sell fried foods, they still take time in $P K K$ activities even though they only contain social gathering and recitation of mothers. It is none other than for mothers to bond together so that when they need each other they can help each other. Like the following confession from Mrs. Yeni (she opened sewing services at home):

“... join the $P K K$ because the activities are good ... social gathering and recitation ... sometimes there are tadarus of the Qur'an and their interpretations ... but indeed there are many recitations from nyai ... good shows" (Source: Interview with Yeni on June 27, 2018).

As such, it shows that women clearly have an interest in $P K K$. This place is the only place that can be used as a meeting place for one "kampung" for mothers. Because according to confession in order to be able to meet each other and if there is a need it is not difficult. Then this can be interpreted if the orientation is still returned to the fulfillment of each household's needs. Because joining the community can make it easier to establish interests with the neighbors. 
Then clearly shows that there is a lame relationship. Women still have to be burdened with managing the community in their villages with the aim of returning to the interests of each family. Whereas husbands have no such obligation, it is clear that there is an asymmetrical power relation. Husbands and wives in poor households in the field of community management. You have no obligation to help your family's interests in building a community. Because the recitation of the taklim at Ndresmo followed by the fathers did not have a direct effect on their families. Obviously only to perpetuate the hereditary habit in the village which prioritizes men, especially clerics and hafid. So that how the production of clerics and hafid must always be good from generation to generation. Whereas women are only the second social class. As a companion for existing ustadz and hafidz regeneration programs.

Also in relation to the public space in this place, when there are events in which men and women gather, women are not allowed to lead. For example, a grand istighosah event, it is forbidden for women to become preachers when there are men in it. So with this it is clearly very gender-biased. Women are constructed not in the realm of leadership. So it is clear that the power relations between men and women are very male-dominated. So that the space for women to move is only limited to the $P K K$ community, which in fact is a collection of women.

So as it is clear in the management of the community there still appears to be male-dominated power relations. And they planted their hegemony for generations through the discourse that men were the main. And women are only male servants. So clearly this becomes a very irony in the midst of a big city like Surabaya. It is still very strong in maintaining a tradition that deeply subordinates women. So clearly the power relation of Michel Foucault is very much happening in the context of the life of gender relations in President. Women consciously accept the discourse that subverts women to the Qur'anic propositions. This knowledge has been perpetuated for generations.

\section{Poor women in development programs in Sidosermo (Ndresmo)}

Ndresmo, if I may mention, really holds very strongly the patriarchal tradition and male power is used as a discourse of truth from generation to generation through the Qur'anic propositions and the doctrine of heaven. We can see this when highlighting the problem of community development. When talking about the affairs of RT-RW, "kelurahan", and the government, the women seem to be anti against this matter and they withdraw far from the problem of public leadership. This resulted in "kampung" development programs such as repairing roads, waterways and others being the responsibility of men. Women don't enter that realm. As some of the following women say:

"When it comes to repairing roads, sewerage, and the government, the father is the one who handles ... the woman is in the area behind ... not good women join in the affairs of men." (Source: Interview with Yeni on June 27, 2018).

When asked the same questions related to development problems in that place, the informants who interviewed all stated that the problem with the Ndresmo program was the domain of the husbands. Whether intentional or not, this clearly indicates that patriarchal hegemony is very strong. Power relations by men to their partners are very dominant. Men always become the main. The discourse passed down from generation to generation in the village. And the severity of men and women giving statements agreeing on the grounds that there is a basis for the verse of the Qur'an when violated will get sin.

So don't be surprised the development problem, women have very little contribution because they have limited themselves. Whereas for the issue of women's empowerment programs, have they been there, and whether women understand and follow. It turned out that data in the field was found if activities outside the home that were often and always followed by women were $P K K$. In this activity only social gathering and recitation and interpretation of the Qur'an. There are no skills education programs such as sewing, baking and others. Even the recognition of mothers if they are self-employed by self-study. As shown in the following data:

"There is no training ... there is no assistance from the village ... I joined the $P K K$, it contained social gathering and recitation ... so far there has been no help going down the mriki from the village ..." (Source: Interview with Heni on June 28, 2018). 
Thus, the activities that are very familiar are $P K K$ and there are no programs that empower them. This seems very ironic because there are many poor women in one community but do not get attention from the government.

Once the researchers asked why the kelurahan was lacking in attention, because kelurahan said in Ndresmo it was the responsibility of the pesantren caregivers in it. Managed by a large family so that the residents in it who are poor can be empowered and become their responsibility. Like the following statement from Rofiq:

“...kelurahan here is not a concern with the residents because here it is seen as the responsibility of the pesantren that helps the citizens ... later if the kelurahan goes down ... the assistance will not be effective ..." (Source: Interview with Rofiq on June 29, 2018).

So we will never find a program to improve the quality of women here in relation to soft skills such as sewing or other entrepreneurs. Because indeed it doesn't work. The mothers also do not understand the programs held by the government so far. They understand that there is a $P K K$ in which the administrators of Fatayat and Muslimat are mixed but there is no program that alleviates poverty. They do not know the variety of empowerment programs set by the government.

So once again it was realized that this place relied on alms as a solution to overcome the lack of funds. Because each year alms that goes to pesantren is relatively large and is spread in Ndresmo's environment. So that it can be seen if "kelurahan" is less sensitive to these conditions. Because the increase in the quality of women or humans in them is not only through material. Training assistance or intensive self-improvement training are also very necessary. Unfortunately this has not been found in the daily life of Ndresmo.

The government through "kelurahan" did not dare to make a fundamental change at Ndresmo. Because in the community there are "kyai" and "nyai" who are saints and have high religious knowledge. So that's why "kelurahan" feels inferior to Ndresmo's people. Besides that, it is also seen that even though patriarchal culture is running from year to year, the government seems to allow because it is a unique local culture. So it is not surprising that patriarchal socio-cultural processes increasingly exist without being able to be changed. This is a lack of conditions for building gender justice. Even though based on the United Nations program in this century gender justice has been initiated in various aspects of life. Equal gender relations should be done.

The study of women that has been done by (Susanti 1998) shows that women always play a double role. But they did not get a fair position. Even what has been done by (Oey \& Soedarti 1991) that women are very responsible in the process of the family economy. So that based on research in the village of Ndresmo increasingly shows women experience oppression in various aspects of life. Poor women are positioned as the second social class and they become the main actors of the family economy. Even worse, the Islamic community itself women are constructed to always submit to their husbands. So that the power relations that occur are very oppressive and restrictive to women. Until the peak is poor women will have difficulty getting out of their poverty circle.

\section{Conclusion}

Asymmetrical power relations occur where women experience subordination, do not get free space and have limited choice of actions. This refers to gender relations that occur in the realm of reproductive, productive and community management. Although women have helped find income for the family economy, this has not been followed by justice in the process of daily life.

Even though it looks very heavy and very asymmetrical about gender relations, the poor women have been constructively educated that all of them have been destined and as part of carrying out religious orders. Because it is written in the Qur'an and if it is violated it will get sin and hell. Therefore the women seemed to agree on the construction of patriarchal culture in the community which had become a discourse from generation to generation. So that the construction of the wrong religion further worsens the condition of women. It's just that women don't make that reality a problem in their lives. This is a major problem that must be resolved. 
And then, speaking of empowerment, there seems to be no government program that is directly felt by women. Because when you say about the government, it becomes a part of men's work. Women are not allowed to enter that domain, thus the discourse is deeply embedded in the women. So that it is very obvious if women experience powerlessness in the development program once again because there is an assumption of pesantren's area with all its culture. Especially poor women are increasingly difficult to get out of poverty.

\section{References}

Berger, Peter L. and Luckman (1990) Tafsir Sosial atas Kenyataan. Edisi Terjemahan. Jakarta: LP3ES. BPS (2018) Standar dan Persentase penduduk miskin Maret 2018. Jakarta: Badan Pusat Statistik. Fakih M (1996) Analisis Gender \& Transformasi Sosial (Gender Analysis \& SociaI Transformation). Yogyakarta: Pustaka Pelajar.

Fiske L \& Shackel R (2015) Gender, poverty and violence: Transitional justice responses to converging processes of domination of women in eastern DRC, Northern Uganda and Kenya. Women's Studies International Forum, 51:110-117.

Foucault M (1990) An Introduction. The History of Sexuality Vol 1 \& 2. New York: Vintage Books.

Foucault M (2002) Power/Knowledge: Selected Interviews dan Other Writings 1972-1977. New York: The Harvaster Press.

Heni (2018) [Personal communication] 28 June.

Heyzer N (1986) Working Women in Southeast Asia: Development Subordinatioan and Emancipation. Milton Keynes: Open University Press.

Moser CON (1993) Gender Planning and Development: Theory Practice and Training. London: Routledge.

Neuman WL (2013) Metodologi Penelitian Sosial: Pendekatan Kualitatif dan Kuantitatif Edisi 7. Jakarta: PT Indeks.

Nurjannah (2018) [Personal communication] 27 June.

Oey GM \& Soedarti S (1991) Strategi Kehidupan Wanita Kepala Rumah Tangga. Jakarta (ID): Biro Pusat Statistik, pp. 51.

Rofiq (2018) [Personal communication] 29 June.

Ruqoyyah (2018) [Personal communication] 28 June.

Santoso (2002) Terjemahan dari Buku Power/Knowledge, Selected Interviewes and Other Writings 1972-1977. Yogyakarta : Bentang Budaya.

Susanti E (1998) Akses perempuan Dalam Lapangan Kerja di Perkotaan (Studi pada Keluarga Miskin di Jawa Timur). Laporan Penelitian Dikti DP3M. Jakarta.

Susanti E (2007) Ketimpangan Gender Dan Ketidakberdayaan Perempuan Miskin Perkotaan. Surabaya: Insan Cendekia.

Waltz A (2016) The women who feed us: Gender empowerment in rural Southern Brazil. Journal of Rural Studies 47:31-40.

Yeni (2018) [Personal communication] 27 June. 